\title{
Apresentação
}

Neste número, o segundo publicado em 2020, Márcio de Carvalho e Izabela Guimarães Guerra Leal retomam a quatro mãos o projeto e a realização tradutória de Haroldo de Campos a partir do capítulo inicial da criação do mundo segundo a Bíblia, um marco na literatura brasileira e ao mesmo tempo o reflexo de longo e multifacetado estudo sobre a tarefa tradutória. A versão haroldiana de Gênesis é comparada à tradução feita pela poeta Josely Vianna Baptista dos cantos da cosmogonia Guarani, em busca de possíveis correspondências entre culturas tão distantes uma da outra, como são as tradições hebraica e um exemplo do mundo expressivo indígena. Um dos méritos desse estudo é recuperar a obra de Campos colocando-a num sistema contínuo da cultura, aproximando-a da realização de Josely e rastreando os universos ao qual pertencem. Sobre a história e a cultura judaica ou produzida por judeus no Brasil e na Europa, escrevem Saul Kirshbaum e Lúcia Chermont respectivamente, assim como Luis S. Krausz, que trata de um gênero particularmente eleito por autores judeus no Velho Mundo. Há também estudos a partir da Bíblia, por André Kanashiro com uma análise de Êxodo 3-15 e Alessandra Conde da Silva, a respeito da imagem e da representação do Rei David na Idade Medieval. Finalmente, textos sobre literatura israelense contemporânea, com foco nos escritores Etgar Keret, por Gabriel Steinberg e Ayelet Gundar-Goshen, por Marian Gabani Gimenez. Tanto Keret quanto a autora mais recente, Ayelet Gundar-Goshen, contribuem para a renovação dos padrões na literatura hebraica contemporânea. Keret é conhecido há mais tempo em português, com suas histórias irônicas e surpreendentes pela inventividade, inclusive na literatura infantil. Gundar-Goshen também trata da cena israelense da atualidade renovando os enfoques já consagrados da geração de Amós $\mathrm{Oz}$ e A.B. Yehoshua entre vários outros ficcionistas de alcance internacional. Finalmente, com o mesmo objetivo de trazer para o público brasileiro uma amostragem da produção cultural israelense na atualidade, publicamos a tradução de trechos das memórias do ator e contador de histórias Vitali H. Ferera, nascido na Turquia e radicado em Israel. Ferera fala, no livro, do passado na antiga comunidade sefardita de Istambul e do presente israelense - a obra aguarda publicação em Israel.

\section{Moacir Amâncio}

